\title{
Building a Pathway for Diversity in Plant Sciences in Argentina: Highlighting the Work of Women Scientists through Virtual Activities ${ }^{\dagger}$
}

\author{
Gabriela Alejandra Auge 1,*, María José de Leone 2, Rocío Deanna ${ }^{3}$, Sonia Oliferuk ${ }^{4}$, \\ Pamela Anahí Ribone ${ }^{5}$ and Elina Welchen ${ }^{6}$ \\ 1 CONICET-iB3, School of Exact and Natural Sciences, University of Buenos Aires, Argentina \\ 2 Fundación Instituto Leloir, IIBBA-CONICET, Argentina; mjdeleone@leloir.org.ar \\ 3 University of Colorado, Boulder, CO 80309, USA; rocio.deanna@colorado.edu \\ 4 Instituto Tecnológico Chascomús (INTECH, CONICET-UNSAM), Argentina; oliferuksonia@gmail.com \\ 5 The Sainsbury Laboratory Cambridge University, Cambridge CB2 1LR, UK; pamela.ribone@slcu.cam.ac.uk \\ 6 Instituto de Agrobiotecnología del Litoral (CONICET-UNL)-FBCB (UNL), Argentina; \\ ewelchen@fbcb.unl.edu.ar \\ * Correspondence: gauge@fbmc.fcen.uba.ar; Tel.: +54-11-5238-8436 \\ + Presented at the 1st International Electronic Conference on Plant Science, 1-15 December 2020; Available \\ online: https://iecps2020.sciforum.net/.
}

Published: 30 November 2020

\begin{abstract}
Encouraging the participation of a diverse workforce in academia increases plurality as it broadens the range of skills, ways of thinking and experiences. Institutions and professional societies have been putting efforts on building plans that help make workplaces, conferences, education and extension programs more relatable to a highly diverse population. Argentina has an overall gender-balanced workforce in the sciences ( $53 \%$ women/total), with an even higher representation in disciplines related to plant sciences. However, media outlets and national conferences related to genetics, botany, plant physiology, ecology and molecular biology, fail to reflect those numbers as the proportion of women invited for interviews, plenary lectures, and symposia falls below $\sim 30 \%$. As a way to increase the visibility of the wealth of plant science topics and experimental approaches in which Argentinian women work, and to facilitate connections among them across the country and abroad, we created the Argentinian Women in Plant Science network (https://argplantwomen.weebly.com/). This group has grown to over 200 members, representing a wide range of career stages and research topics. Since April, and taking advantage of the confinement situation, our weekly webinar series highlighting women plant scientists has reached an average audience of 60-70 participants, with a record of 100. Recently, we have begun a series of open professional development webinars to reach a wider public. Our first webinar, focused on Scientific poster design, had 250 participants, most of them undergrad and graduate students from all over the country covering a diverse range of disciplines, including the social sciences. Even though we have immersed ourselves in the plant science community with our weekly seminars, we have expanded our goals with activities aimed to reach out to a much wider audience with webinars and teacher training workshops, hopefully making plant science more attainable to all.
\end{abstract}

Keywords: women; communication; network; gender-equality

\section{Introduction}

A diverse, gender-balanced environment improves working and learning experiences in the science workforce as a whole, increasing collective performance [1-4]. However, according to 
UNESCO, women account for a minority of the research workforce worldwide [5]. The numbers reflect gender disparity in scientific society leadership, conference speakers, journal editors and editorial board members, professorships, participation in media outlets, etc [6-9]. Many efforts have been made in recent years to overcome this problem and increase women representation in the sciences [10-16], but there is still a long road to break the 'glass ceiling' [17].

Argentina has an overall gender-balanced science workforce $(\sim 53 \%)$ [5], with even higher proportions of women in disciplines related to plant science (Figure 1). However, many sciencerelated activities, especially in conferences and media outlets, fail to comply with this representation. With a group of Argentinian women plant scientists, we created the ARG Plant Women network to increase women visibility and interaction across the plant sciences in the country. Our objectives are to provide a network that facilitates connections and communication among its participants, to develop professional development opportunities, and to show the wealth of subdisciplines and experimental approaches used at work. In this short manuscript we would like to summarize gender representation numbers in our country, actions taken by the network and its initial outcomes.
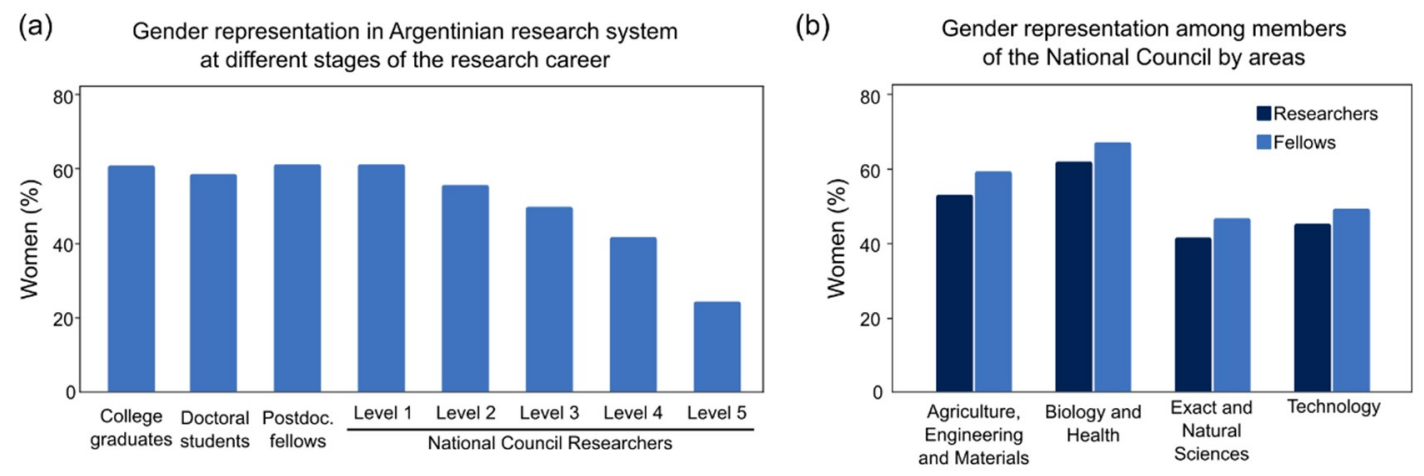

(c)

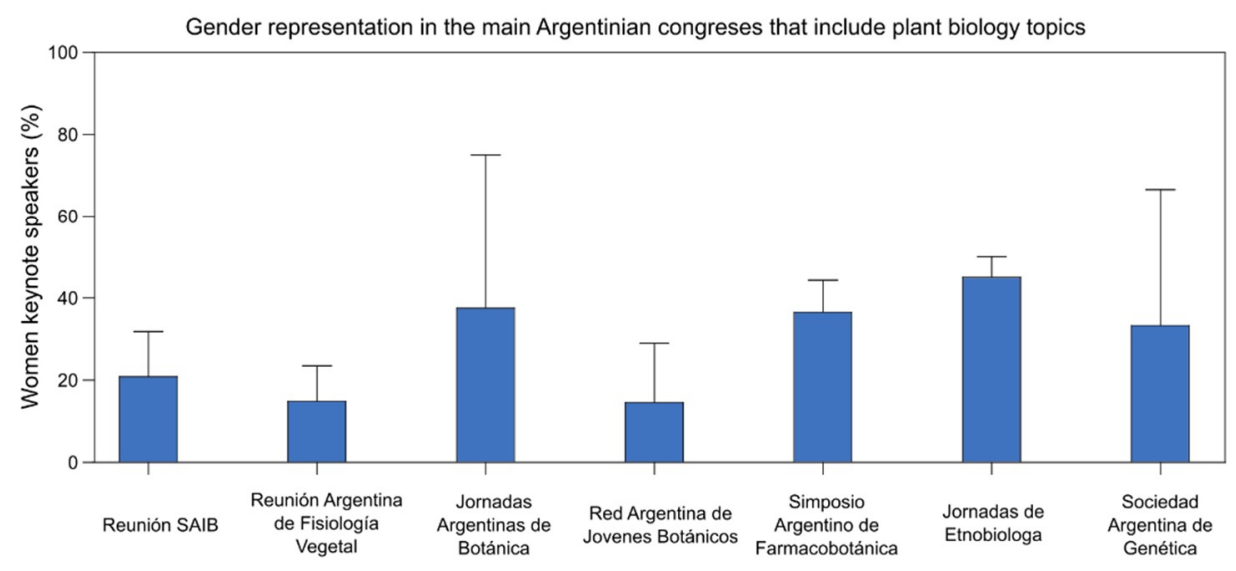

Figure 1. Gender representation of scientists in Argentina. (a) Proportion of women at different stages of the academic path (data: SICYTAR, Science and Technology Information Portal, and DIU, Department of University Information, Ministry of Education, Argentina [18,19]). (b) Proportion of women (National Council researchers, dark blue, and doctoral and postdoctoral fellows, light blue) in the main research areas that pertain to plant science (data: CONICET, National Council database). (c) Proportion of women invited as keynote speakers in national conferences. Data represent the average of the proportion of invited women scientists in the last 3 conferences of each area; 'Reunión SAIB', annual meeting of the Society for Research in Biochemistry and Molecular Biology; 'Reunión Argentina de Fisiología Vegetal', biannual meeting of the Society of Plant Physiology; 'Jornadas Argentinas de Botánica', biannual meeting of the Botanical Society; 'Red Argentina de Jóvenes Botánicos', biannual meeting of the Young Botanists Network; 'Simposio Argentino de Farmacobotánica', Pharmacobotany Symposium (every 4 years); 'Jornadas de Etnobiología', biannual Ethnobiology meeting; 'Sociedad Argentina de Genética', annual meeting of the Genetics Society. 


\section{Gender Representation in the Plant Sciences in Argentina}

Argentina is among the few countries in the world where gender parity in the sciences is reached [5]. Women represent most of the college graduates, doctoral students and postdoctoral researchers (Figure 1a). After a transition to an independent career as researchers of the National Council (Consejo Nacional de Investigaciones Científicas y Técnicas, CONICET), the most common path taken by academics in the country, we observe a sharp drop in the proportion of women as researchers are promoted to higher level positions (Figure 1a). This is a common trend in other positions related to education and science at universities and organizations in Argentina: fewer women in decision making positions (data not shown). Particularly in the major research areas of the National Council that include plant biology related topics, both women researchers and fellows are always well-represented (Figure 1b). However, we fail to see this gender inclusivity in speakers at national conferences related to genetics, botany, plant physiology, ecology and molecular biology, as the proportion of women invited for plenary lectures do not reflect those numbers, and falls below $\sim 30 \%$ (Figure 1c).

\section{ARG Plant Women: The Argentinian Network of Women in Plant Sciences}

Even though plant sciences is a field with an overall good representation of women in our country, we observed that many seminars, conferences and activities fail to represent such numbers (Figure 1c). With the idea of increasing visibility of the many women that work in the plant sciences in the country, we created the network of Argentinian women in plant sciences, or ARG Plant Women [20]. Facing the lockdown due to the pandemic, we started thinking about ways to gather members of our network, and to create a virtual space we could use to know each other. The network now counts with over 200 members, with an extended community of $\sim 250$ people. The first activity we embarked on was a weekly virtual seminar series in which we invite women plant scientists, working in Argentina and abroad, to present their research and other science related activities (Figure 2a, Appendix A). From April to November, we have held 28 seminars with an average audience of 60 people, who stayed connected for most of the seminar (Figure $2 b, c)$. Our speakers are scientists at different stages of their careers, and they work in many subdisciplines within plant science (Figure 2c). Appendix A shows a comprehensive list of the speakers, date of the seminars, affiliation and role, field of work and seminar title. 

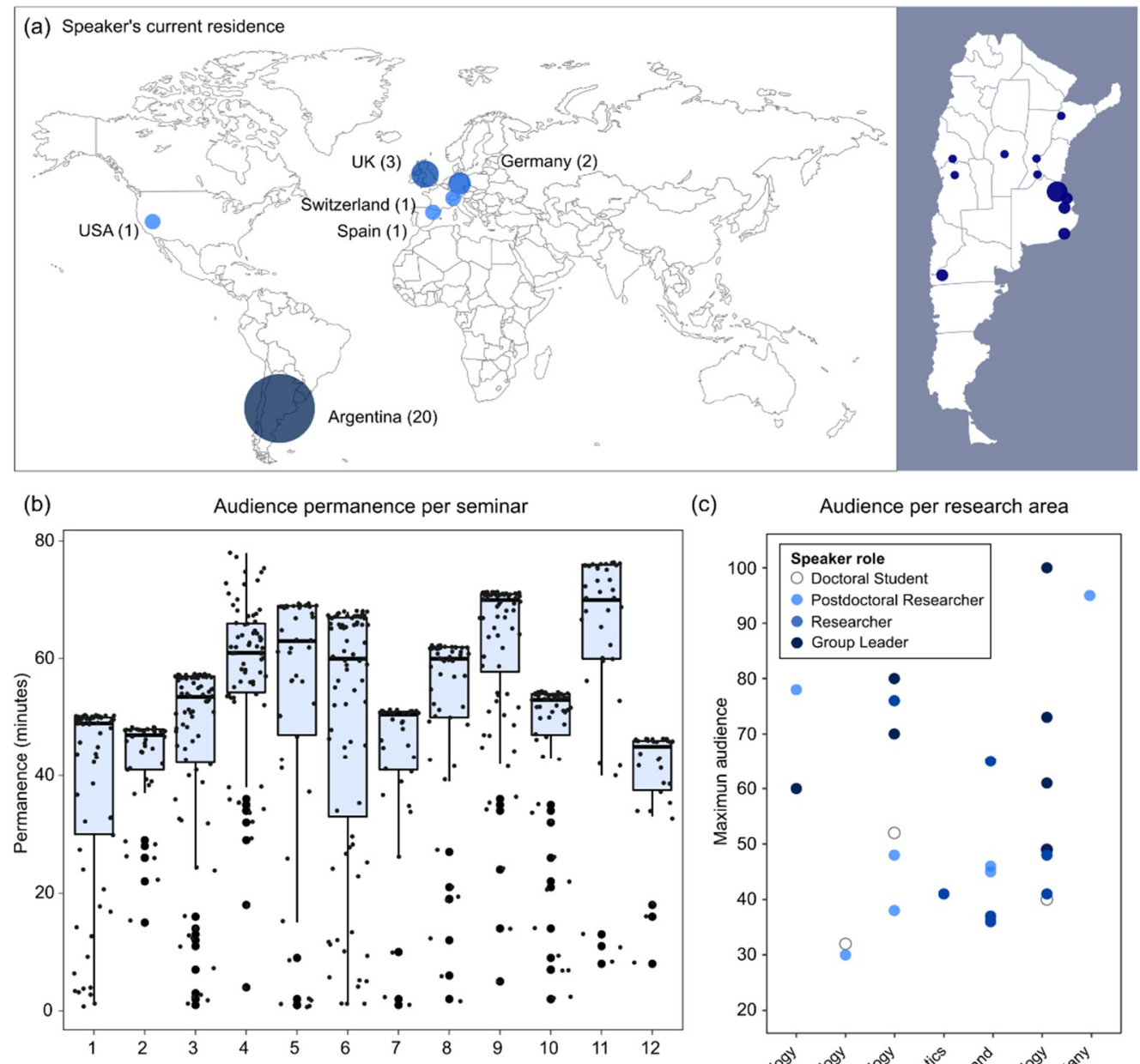

(c) Audience per research area

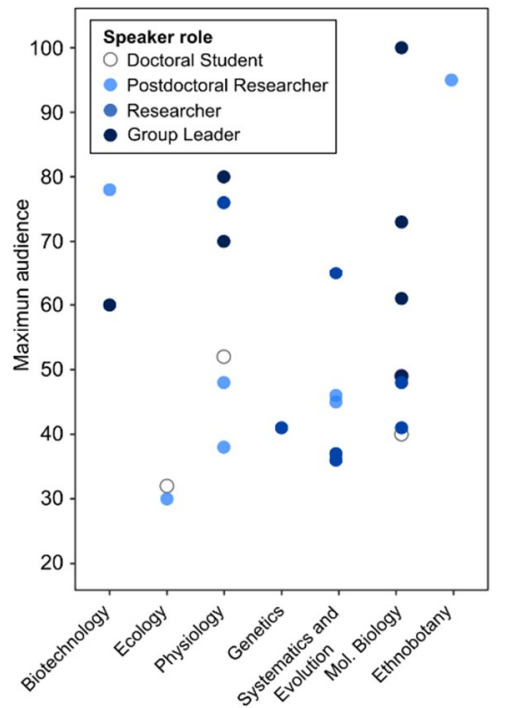

Figure 2. ARG Plant Women seminars. (a) Location and number of speakers per country in parenthesis. (b) Boxplots showing permanence in minutes of each person in the audience of the first 12 seminars (April-June 2020), note the median is close to the highest permanence points for all the seminars indicating most of the audience remains connected during the whole presentation. (c) Peak audience for each seminar (except the last 3 ones, y-axis) separated by subdiscipline in the plant sciences (x-axis) and career stage (color gradient).

We have also started a series of free open professional development webinars with the objectives of providing useful tools and reaching out to a wider public. The first two webinars (science poster design and effective presentations part I) counted with over 200 registrations each, an average of 100 active participants during the webinar and continuous participation in two dedicated Slack channels. The audience exceeded the plant science field as we had participants from the life sciences in general, but also some from the social sciences and even high school students. We observed great interest in the webinars and participation from undergraduate and postgraduate students, showing there is a need for this kind of courses that complement scientific training and personal development. We have scheduled two more webinars for before the end of the calendar year 2020 (effective presentations part II and effective communication skills). We have received many requests to repeat our webinars and to develop new workshops on other topics (public policy, student-mentor relationship, grant and fellowship applications, etc). In addition, and if the pandemic allows in-person conferences, we will join scientific meetings to offer a shorter version of these webinars, potentially increasing the audience reached. 


\section{Outcomes and Self-Evaluation}

To measure the impact and level of acceptance of our seminar series, in July 2020 we conducted a survey among members of the network and seminar attendees. Our weekly virtual seminar series is highly rated among our network (Figure 3a). Half of the respondents considered the seminars changed their point of view about topics covered and the majority considered that change to be positive (Figure 3b). Many of the respondents have also taken actions as a result of attending the seminars, such as contacting speakers to explore new collaboration projects (Figure 3c). People highly valued different aspects of the seminars, like their format, the speaker selection and interaction with them, and also the availability of the recorded seminars on YouTube [21]. We have received an outstanding number of optimistic reviews and encouragement for the work we have done so far (Figure 3d). Nevertheless, we are still thinking about new ways to maintain the interest for the seminar series, increase diversity of themes and geographical representation, and at the same time to take into consideration the potential effects of the eventual re-opening of the workplaces for the next cycle 2021.

(a)

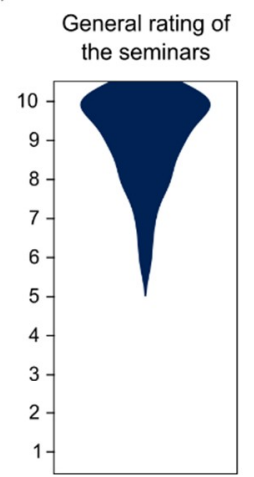

(b)

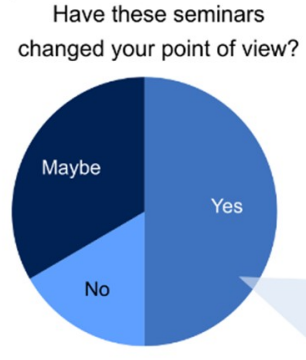

Do you consider that change to be positive?

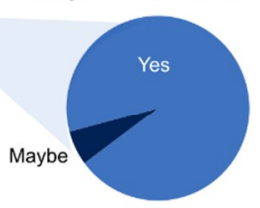

(c)

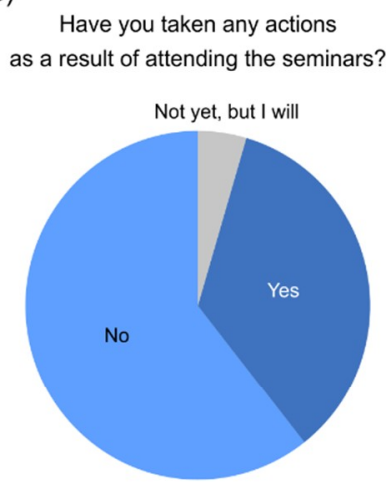

(d)

"I apreciate the topic diversity and the federal coverage. I don't live in a big city, so this kind of events allow me to be in contact with other scientists, keep me up-to-date on what's going on in the area and provide me a space that I don't have at my workplace."
"I appreciate the relaxed environment that you promote on the seminars, that helps the interaction with the speakers to be more fluent."

Figure 3. Seminars rating. (a) General rating of the seminars showing overall replies about quality. (b) Proportion of respondents that consider the seminars to effectively have changed ('Yes'), might have changed ('Maybe') or have not changed ('No') their point of view; and for the ones that responded 'Yes', proportion of respondents who considered that change to be positive or not. (c) Proportion of respondents that have taken ('Yes'), will take ('Not yet, but I will') and have not taken actions ('No') after attending the seminars. (d) Exemplary comments left by the respondents.

On a similar survey, our webinars have received an average rate of 9.5 out of 10 points. The audience positively valued the duration, contents presented and format of the webinars, as well as interaction with and clarity of the speakers, extra material provided and proposed activities, plus communication through the Slack channels. In average, 97\% of the audience considered that they would apply the knowledge acquired in the webinars in their work. The large acceptance of these webinars shows we found a niche that needed to be covered for the career development of scientists, not only in our discipline, but in the whole Argentinian scientific community.

Engagement with our social platforms is active, with many followers and subscribers, as shown by metrics indicating interaction with our posts and publications (Table 1). The seminar videos, uploaded to the YouTube channel after the presentations, gathered over 1800 views. 
Table 1. Engagement in social platforms: statistics from our Twitter, YouTube and Instagram accounts by November 2020 .

\begin{tabular}{ccccc}
\hline Social Platform & Subscribers/Followers & Impressions & Likes & Other Metrics \\
\hline Twitter & 666 & $31.5 \mathrm{~K} /$ month & $\sim 340 /$ month & \\
\hline YouTube [21] & 94 & $34.3 \mathrm{~K}$ total & $\sim 120$ total & $\sim 1800$ total views \\
\hline Instagram & 508 & & $\sim 280 /$ post & \\
\hline
\end{tabular}

\section{Next Steps}

Our aim is to make this network grow larger, reaching to many more places and scientists in our country we have not previously reached. We will keep working on increasing geographical representation and creating connections between speakers and audience, building stronger connections with Argentinian women plant scientists that are residing abroad, and developing more tools for personal development and knowledge of the intricate scientific system in our country. Even after re-opening of workplaces in 2021, we will keep working on a weekly seminar schedule in which graduate students, postdocs and researchers can show their work, as well as monthly webinars on different topics. We will develop teacher training workshops with the goal to incorporate more plant sciences in schools, hopefully encouraging more children and teenagers to pursue a career as plant biologists and botanists.

\section{Conclusions}

Even facing an ongoing pandemic, we have built a pathway to increase diversity in the plant sciences in Argentina. We believe there are many ways to promote the engagement and visibility of the work performed by women scientists, and we are delighted to see our work helps reach this goal. From this southern part of the world, we encourage to extend our planification to other countries and communities with the hope that this could be applied to further communication in science.

Author Contributions: G.A.A., M.J.d.L., R.D., S.O. and P.A.R. have gathered the data and wrote the manuscript. E.W. has contributed to the critical reading and final edition of the manuscript. All authors have read and agreed to the published version of the manuscript.

Acknowledgments: G.A.A. is a researcher of the National Council (Consejo Nacional de Investigaciones Científicas y Técnicas, CONICET) and is supported by Agencia Nacional de Promoción de la Investigación, el Desarrollo Tecnológico y la Innovación (Agencia I+D+i, FONCyT, grants PICT 2016-0389 and PICT 2017-2656). M.J.dL. is supported by a CONICET fellowship. R.D. is supported by the National Science Foundation (DEB1557871) and Agencia I+D+i (FONCyT, grant PICT 2017-2370). S. O. is supported by a fellowship from Agencia I+D+i (FONCyT, grant PICT 2016-0621). P.A.R. is supported by an EMBO long-term fellowship. E.W. is a researcher of the National Council (CONICET) and is supported by Agencia I+D+i (FONCyT, PICT 2017-2350). We would like to thank every member of the ARG Plant Women network and the plant science community at large for the continuous support to all our initiatives.

Conflicts of Interest: The authors declare no conflict of interest. 
Appendix A. List of Seminar Speakers Showing Seminar Date, Affiliation, Role Field and Seminar Title. Videos Available in Our YouTube Channel.

\begin{tabular}{|c|c|c|c|c|c|}
\hline Date & Speaker & Affiliation & Role & Field & Topic \\
\hline $6 / 4 / 2020$ & $\begin{array}{l}\text { Rocío } \\
\text { Deanna }\end{array}$ & $\begin{array}{c}\text { CU Boulder, } \\
\text { US/Natural } \\
\text { History } \\
\text { Museum, UK }\end{array}$ & $\begin{array}{l}\text { Postdoctoral } \\
\text { Researcher }\end{array}$ & $\begin{array}{l}\text { Systematics } \\
\text { and Evolution }\end{array}$ & $\begin{array}{l}\text { Evolución de la tribu Physalideae } \\
\text { (Solanaceae) + Difusión de ciencia }\end{array}$ \\
\hline $13 / 4 / 2020$ & Anahí Yáñez & $\begin{array}{l}\text { CIGEOBIO, } \\
\text { CONICET- } \\
\text { UNSJ, AR } \\
\end{array}$ & $\begin{array}{l}\text { Postdoctoral } \\
\text { Researcher }\end{array}$ & Genetics & $\begin{array}{c}\text { Retroelementos como marcadores } \\
\text { moleculares en ají (Capsicum, } \\
\text { Solanaceae) }\end{array}$ \\
\hline $20 / 4 / 2020$ & $\begin{array}{l}\text { Mariana } \\
\text { Corigliano }\end{array}$ & $\begin{array}{c}\text { INTECH, } \\
\text { CONICET- } \\
\text { UNSAM, AR }\end{array}$ & Researcher & Biotechnology & $\begin{array}{c}\text { HSP90 de plantas como } \\
\text { inmunomoduladores de la RI + } \\
\text { Divulgación y extensión }\end{array}$ \\
\hline $27 / 4 / 2020$ & $\begin{array}{l}\text { Gabriela } \\
\text { Amodeo }\end{array}$ & $\begin{array}{l}\text { FCEN-UBA \& } \\
\text { IBBEA UBA- } \\
\text { CONICET, AR }\end{array}$ & $\begin{array}{l}\text { Group } \\
\text { Leader }\end{array}$ & Physiology & $\begin{array}{l}\text { Acuaporinas en plantas: los nuevos } \\
\text { desafíos }\end{array}$ \\
\hline $5 / 5 / 2020$ & $\begin{array}{l}\text { Laura Las } \\
\text { Peñas }\end{array}$ & $\begin{array}{l}\text { IMBIV, } \\
\text { CONICET- } \\
\text { UNC, AR } \\
\end{array}$ & Researcher & $\begin{array}{l}\text { Systematics } \\
\text { and Evolution }\end{array}$ & $\begin{array}{l}\text { Diversidad de Cactaceae: aspectos } \\
\text { genéticos, morfológicos y ecológicos }\end{array}$ \\
\hline $11 / 5 / 2020$ & $\begin{array}{l}\text { Gabriela } \\
\text { Auge }\end{array}$ & $\begin{array}{l}\text { iB3, FCEN- } \\
\text { UBA, AR }\end{array}$ & $\begin{array}{l}\text { Group } \\
\text { Leader }\end{array}$ & Physiology & $\begin{array}{l}\text { Vías de floración regulan } \\
\text { pleiotrópicamente dormición y } \\
\text { germinación de semillas }\end{array}$ \\
\hline $18 / 5 / 2020$ & $\begin{array}{l}\text { Agostina } \\
\text { Sassone } \\
\end{array}$ & $\begin{array}{l}\text { IPK - Leibniz } \\
\text { Institute, DE }\end{array}$ & $\begin{array}{c}\text { Postdoctoral } \\
\text { Researcher }\end{array}$ & $\begin{array}{c}\text { Systematics } \\
\text { and Evolution }\end{array}$ & $\begin{array}{l}\text { Dilucidando la taxonomía de los ajos } \\
\text { sudamericanos (tribu Leucocoryneae) }\end{array}$ \\
\hline $1 / 6 / 2020$ & $\begin{array}{c}\text { Gabriela } \\
\text { Pagnussat }\end{array}$ & $\begin{array}{l}\text { IIB, CONICET- } \\
\text { UNMDP, AR }\end{array}$ & $\begin{array}{l}\text { Group } \\
\text { Leader }\end{array}$ & $\begin{array}{c}\text { Molecular } \\
\text { Biology } \\
\end{array}$ & $\begin{array}{l}\text { Síntesis de homocastasterona en el } \\
\text { gametofito femenino de } A \text {. thaliana }\end{array}$ \\
\hline $8 / 6 / 2020$ & $\begin{array}{c}\text { Martina } \\
\text { Legris }\end{array}$ & $\begin{array}{l}\text { Fankhauser's } \\
\text { lab, UNIL, CH }\end{array}$ & $\begin{array}{c}\text { Postdoctoral } \\
\text { Researcher }\end{array}$ & Physiology & $\begin{array}{c}\text { Rol de los fotorreceptores en el control } \\
\text { del desarrollo en Arabidopsis }\end{array}$ \\
\hline $16 / 6 / 2020$ & Paula Casati & $\begin{array}{l}\text { CEFOBI, } \\
\text { CONICET- } \\
\text { UNR, AR } \\
\end{array}$ & $\begin{array}{l}\text { Group } \\
\text { Leader }\end{array}$ & $\begin{array}{l}\text { Molecular } \\
\text { Biology }\end{array}$ & $\begin{array}{c}\text { Flavone biosynthesis and salicylic acid } \\
\text { hydroxylation in plants }\end{array}$ \\
\hline $25 / 6 / 2020$ & $\begin{array}{l}\text { Mariana } \\
\text { Grossi }\end{array}$ & $\begin{array}{c}\text { División } \\
\text { Plantas } \\
\text { Vasculares, } \\
\text { Museo de La } \\
\text { Plata, AR } \\
\end{array}$ & $\begin{array}{l}\text { Postdoctoral } \\
\text { Researcher }\end{array}$ & $\begin{array}{l}\text { Systematics } \\
\text { and Evolution }\end{array}$ & $\begin{array}{c}\text { Análisis comparativo de caracteres } \\
\text { reproductivos en Eupatorieae } \\
\text { (Asteraceae) }\end{array}$ \\
\hline $29 / 6 / 2020$ & Ana Srur & $\begin{array}{l}\text { IANIGLA- } \\
\text { CONICET, AR }\end{array}$ & Researcher & Ecology & $\begin{array}{c}\text { Dinámica de los bosques en los Andes } \\
\text { patagónicos argentinos: } \\
\text { dendroecología }\end{array}$ \\
\hline $3 / 8 / 2020$ & $\begin{array}{c}\text { Debora } \\
\text { Rondanini } \\
\end{array}$ & $\begin{array}{l}\text { FAUBA, UBA, } \\
\text { AR } \\
\end{array}$ & Researcher & Physiology & $\begin{array}{c}\text { Avances en ecofisiología de colza- } \\
\text { canola }\end{array}$ \\
\hline $10 / 8 / 2020$ & $\begin{array}{l}\text { Eugenia } \\
\text { Zanetti }\end{array}$ & $\begin{array}{l}\text { IBBM-FCE- } \\
\text { UNLP, } \\
\text { CONICET, AR } \\
\end{array}$ & $\begin{array}{l}\text { Group } \\
\text { Leader }\end{array}$ & $\begin{array}{l}\text { Molecular } \\
\text { Biology }\end{array}$ & $\begin{array}{c}\text { To keep or not to keep: mRNA } \\
\text { stability and translatability in root } \\
\text { nodule symbiosis }\end{array}$ \\
\hline 24/8/2020 & $\begin{array}{c}\text { Alicia Lopez } \\
\text { Mendez } \\
\end{array}$ & $\begin{array}{l}\text { FCA UNMDP, } \\
\text { CONICET, AR } \\
\end{array}$ & Researcher & $\begin{array}{l}\text { Systematics } \\
\text { and Evolution }\end{array}$ & $\begin{array}{l}\text { Nuestras líneas de investigación en } \\
\text { botánica }\end{array}$ \\
\hline $31 / 8 / 2020$ & Julia Qüesta & CRAG, ESP & $\begin{array}{l}\text { Group } \\
\text { Leader }\end{array}$ & $\begin{array}{c}\text { Molecular } \\
\text { Biology }\end{array}$ & Epigenetic memory in plants \\
\hline $7 / 9 / 2020$ & $\begin{array}{l}\text { Victoria } \\
\text { Gastaldi }\end{array}$ & IAL, AR & $\begin{array}{l}\text { PhD } \\
\text { Student }\end{array}$ & $\begin{array}{l}\text { Molecular } \\
\text { Biology }\end{array}$ & $\begin{array}{c}\text { Las proteínas TCPs y su participación } \\
\text { en la elongación del estambre en } A \text {. } \\
\text { thaliana }\end{array}$ \\
\hline $14 / 9 / 2020$ & $\begin{array}{c}\text { María Laura } \\
\text { Vidoz } \\
\end{array}$ & $\begin{array}{l}\text { IBONE,UNNE, } \\
\text { CONICET, AR } \\
\end{array}$ & Researcher & Physiology & $\begin{array}{c}\text { Respuestas adaptativas de las plantas } \\
\text { de tomate a la inundación }\end{array}$ \\
\hline $21 / 9 / 2020$ & Ana Ladio & $\begin{array}{l}\text { INIBIOMA, } \\
\text { AR }\end{array}$ & Researcher & Ethnobotany & $\begin{array}{c}\text { Etnobotánica patagónica: vínculos con } \\
\text { las plantas y su rol en conservación } \\
\text { biocultural }\end{array}$ \\
\hline
\end{tabular}




\begin{tabular}{|c|c|c|c|c|c|}
\hline $28 / 9 / 2020$ & $\begin{array}{l}\text { Pamela } \\
\text { Ribone }\end{array}$ & SLCU, UK & $\begin{array}{l}\text { Postdoctoral } \\
\text { Researcher }\end{array}$ & $\begin{array}{l}\text { Molecular } \\
\text { Biology }\end{array}$ & $\begin{array}{l}\text { Regulación de la expresión génica } \\
\text { mediada por uORFs }\end{array}$ \\
\hline $5 / 10 / 2020$ & $\begin{array}{c}\text { Luciana } \\
\text { Bianchimano }\end{array}$ & $\begin{array}{l}\text { FIL/IBBA- } \\
\text { CONICET, AR }\end{array}$ & $\begin{array}{l}\text { PhD } \\
\text { Student }\end{array}$ & Physiology & $\begin{array}{c}\text { Respuestas de las plantas al desafío } \\
\text { impuesto por altas densidades de } \\
\text { cultivo }\end{array}$ \\
\hline $19 / 10 / 2020$ & $\begin{array}{l}\text { María } \\
\text { Florencia } \\
\text { Ercoli }\end{array}$ & $\begin{array}{l}\text { Department of } \\
\text { Plant } \\
\text { Pathology, UC } \\
\text { Davis, US }\end{array}$ & $\begin{array}{l}\text { Postdoctoral } \\
\text { Researcher }\end{array}$ & $\begin{array}{l}\text { Molecular } \\
\text { Biology }\end{array}$ & $\begin{array}{l}\text { RaxX modifies the host environment } \\
\text { by mimicking a plant peptide hormone }\end{array}$ \\
\hline $26 / 10 / 2020$ & $\begin{array}{l}\text { Marina } \\
\text { Clemente }\end{array}$ & $\begin{array}{c}\text { INTECH, } \\
\text { CONICET- } \\
\text { UNSAM, AR }\end{array}$ & $\begin{array}{l}\text { Group } \\
\text { Leader }\end{array}$ & Biotechnology & $\begin{array}{c}\text { Las plantas para la producción de } \\
\text { proteínas de uso terapéutico + Ciencia } \\
\text { en el bar }\end{array}$ \\
\hline $2 / 11 / 2020$ & $\begin{array}{l}\text { Julieta } \\
\text { Cagnacci }\end{array}$ & $\begin{array}{l}\text { IIFA, INTA- } \\
\text { CONICET, AR }\end{array}$ & $\begin{array}{l}\text { PhD } \\
\text { Student }\end{array}$ & Ecology & $\begin{array}{c}\text { El impacto de diferentes ambientes } \\
\text { naturales a lo largo de la altitud en las } \\
\text { dinámicas de regeneración de dos } \\
\text { especies de Nothofagus en los Andes } \\
\text { Patagónicos }\end{array}$ \\
\hline $9 / 11 / 2020$ & $\begin{array}{l}\text { Daniela } \\
\text { Sueldo }\end{array}$ & $\begin{array}{l}\text { SLS, Warwick } \\
\text { University, UK }\end{array}$ & $\begin{array}{l}\text { Group } \\
\text { Leader }\end{array}$ & $\begin{array}{c}\text { Molecular } \\
\text { Biology }\end{array}$ & $\begin{array}{c}\text { Plant immune cell death: execution } \\
\text { and multicellular coordination }\end{array}$ \\
\hline $16 / 11 / 2020$ & $\begin{array}{l}\text { Florencia } \\
\text { Yannelli }\end{array}$ & $\begin{array}{l}\text { Ecological } \\
\text { Novelty } \\
\text { group, FU- } \\
\text { Berlin, DE } \\
\end{array}$ & Researcher & Ecology & $\begin{array}{l}\text { Restauración ecológica en el contexto } \\
\text { de las plantas invasoras }\end{array}$ \\
\hline $23 / 11 / 2020$ & $\begin{array}{c}\text { Rocío } \\
\text { Tognacca }\end{array}$ & $\begin{array}{l}\text { IFIBYNE, } \\
\text { UBA- } \\
\text { CONICET, AR } \\
\end{array}$ & $\begin{array}{l}\text { Postdoctoral } \\
\text { Researcher }\end{array}$ & $\begin{array}{l}\text { Molecular } \\
\text { Biology }\end{array}$ & $\begin{array}{c}\text { Regulación del splicing alternativo } \\
\text { durante la germinación inducida por } \\
\text { luz }\end{array}$ \\
\hline $30 / 11 / 2020$ & $\begin{array}{l}\text { Agustina } \\
\text { Yañez }\end{array}$ & $\begin{array}{c}\text { MACN- } \\
\text { CONICET, AR }\end{array}$ & Researcher & $\begin{array}{l}\text { Systematics } \\
\text { and Evolution }\end{array}$ & $\begin{array}{c}\text { Biodiversidad de Helechos y Licofitas } \\
\text { en áreas protegidas de la provincia de } \\
\text { Misiones: } 10 \text { años de trabajo en la selva } \\
\text { Paranaense }\end{array}$ \\
\hline
\end{tabular}

\section{References}

1. Nielsen, M.W.; Alegria, S.; Börjeson, L.; Etzkowitz, H.; Falk-Krzesinski, H.J.; Joshi, A.; Leahey, E.; SmithDoerr, L.; Woolley, A.W.; Schiebinger, L. Opinion: Gender diversity leads to better science. Proc. Natl. Acad. Sci. USA 2017, 114, 1740-1742, doi:10.1073/pnas.1700616114.

2. Woolley, A.W.; Chabris, C.F.; Pentland, A.; Hashmi, N.; Malone, T.W. Evidence for a Collective Intelligence Factor in the Performance of Human Groups. Science 2010, 330, 686-688, doi:10.1126/science.1193147.

3. Woolley, A.W.; Aggarwal, I.; Malone, T.W. Collective Intelligence and Group Performance. Curr. Dir. Psychol. Sci. 2015, 24, 420-424, doi:10.1177/0963721415599543.

4. Elsevier 3 Reasons Gender Diversity is Crucial to Science. Available online: https://www.elsevier.com/connect/3-reasons-gender-diversity-is-crucial-to-science (accessed on 10 November 2020).

5. UNESCO Women in Science; 2019; p. FS/2019/SCI/55.

6. Potvin, D.A.; Burdfield-Steel, E.; Potvin, J.M.; Heap, S.M. Diversity begets diversity: A global perspective on gender equality in scientific society leadership. PLoS ONE 2018, 13, e0197280, doi:10.1371/journal.pone.0197280.

7. Mauleón, E.; Hillán, L.; Moreno, L.; Gómez, I.; Bordons, M. Assessing gender balance among journal authors and editorial board members. Scientometrics 2013, 95, 87-114, doi:10.1007/s11192-012-0824-4.

8. Adams, R.B.; Kirchmaier, T. Women on Boards in Finance and STEM Industries. Am. Econ. Rev. 2016, 106, 277-281, doi:10.1257/aer.p20161034.

9. Wang, M.-T.; Degol, J.L. Gender Gap in Science, Technology, Engineering, and Mathematics (STEM): Current Knowledge, Implications for Practice, Policy, and Future Directions. Educ. Psychol. Rev. 2017, 29, 119-140, doi:10.1007/s10648-015-9355-x.

10. Martin, J.L. Ten Simple Rules to Achieve Conference Speaker Gender Balance. PLoS Comput. Biol. 2014, 10, e1003903, doi:10.1371/journal.pcbi.1003903. 
11. Kong, S.; Carroll, K.; Lundberg, D.; Omura, P.; Lepe, B. Reducing gender bias in STEM. MIT Sci. Policy Rev. 2020, 1, 55-63, doi:10.38105/spr.11kp6lqr0a.

12. Athena Swan Charter I Advance HE. Available online: https://www.advance-he.ac.uk/equalitycharters/athena-swan-charter (accessed on 11 November 2020).

13. Best, K.L.; Sanwald, U.; Ihsen, S.; Ittel, A. Gender and STEM in Germany: Policies Enhancing Women's Participation in Academia. Int. J. Gender Sci. Technol. 2013, 5, 292-304.

14. Biaswatchneuro. Available online: https://biaswatchneuro.com/ (accessed on 11 November 2020).

15. Moss-Racusin, C.A.; van der Toorn, J.; Dovidio, J.F.; Brescoll, V.L.; Graham, M.J.; Handelsman, J. A "Scientific Diversity" Intervention to sReduce Gender Bias in a Sample of Life Scientists. LSE 2016, 15, ar29, doi:10.1187/cbe.15-09-0187.

16. Brewer, P.R.; Ley, B.L. “Where My Ladies At?": Online Videos, Gender, and Science Attitudes among University Students. Int. J. Gender Sci. Technol. 2018, 9, 278-297.

17. Weyer, B. Twenty years later: Explaining the persistence of the glass ceiling for women leaders. Women Manag. Rev. 2007, 22, 482-496, doi:10.1108/09649420710778718.

18. Portal de Sicytar. Available online: http://sicytar.mincyt.gob.ar/ (accessed on 11 November 2020).

19. Spu Sceu. Available online: http://estadisticasuniversitarias.me.gov.ar/\#/home (accessed on 12 November 2020).

20. Arg Plant Women. Available online: https://argplantwomen.weebly.com/ (accessed on 12 November 2020).

21. Biólogas Argentina-YouTube. Available online: https://www.youtube.com/channel/UCK6Kt29dfHLOblmUxc0YhOQ (accessed on 12 November 2020).

Publisher's Note: MDPI stays neutral with regard to jurisdictional claims in published maps and institutional affiliations.

(C) 2020 by the authors. Licensee MDPI, Basel, Switzerland. This article is an open access article distributed under the terms and conditions of the Creative Commons Attribution (CC BY) license (http://creativecommons.org/licenses/by/4.0/). 